\title{
Studies on drying characteristic, nutritional composition, and antioxidant properties of Stevia rebaudiana (Bertoni) leaves
}

\author{
Yolanda B. Moguel-Ordóñez, Diana L. Cabrera-Amaro1, Maira R. Segura-Campos ${ }^{2}$,Jorge C. Ruiz-Ruiz ${ }^{3 *}$ \\ ${ }^{1}$ Instituto Nacional de Investigaciones Forestales, Agrícolas y Pecuarias, Campo Experimental Mocochá, Km 25, Mocochá, \\ Yucatán, México \\ ${ }^{2}$ Facultad de Ingeniería Química, Universidad Autónoma de Yucatán, Periférico Norte Km. 33.5, Col. Chuburná de Hidalgo Inn, \\ Mérida, Yucatán, México \\ ${ }^{3}$ Departamento de Ingeniería Química-Bioquímica, Instituto Tecnológico de Mérida, Av. Tecnológico Km 4.5 S/N, C.P. 97118 , \\ Mérida, Yucatán, México
}

Received October 28, 2014; accepted June 15, 2015

\begin{abstract}
A b s t r a c t. Drying characteristics of Stevia rebaudiana (Bertoni) leaves using radiation drying, convection drying, sun drying, and shade drying treatments were investigated in a convective type. Results for all treatments indicated that drying took place in the falling rate period. The chroma of the dried samples ranged between 29.66 and 23.85. Convection and shade drying samples were found better in colour and had the highest content of total pigments. The proximate and fibre composition were affected by the drying treatments. Extracts obtained from convection drying and shade drying leaves exhibited higher values of Trolox equivalent antioxidant capacities 416.89-423.64 mM $\mathrm{mg}^{-1}$ and ferric reducing power $85.19-87.97 \%$. These extracts also showed ion chelating capacity $59.05-60.21 \%$ for $\mathrm{Cu}^{+2}$ and $55.05-$ $59.11 \%$ for $\mathrm{Fe}^{+2}$. The results indicate that it is possible to select the drying treatment to obtain the best nutritional and biological properties. Convection drying and shade drying were the least aggressive treatments and leaf powders obtained by these drying methods could be used as sources of nutrients, fibre, and antioxidant compounds.
\end{abstract}

K e y w o r d s: Stevia rebaudiana (Bertoni), drying methods, nutritional composition, antioxidant properties

\section{INTRODUCTION}

Stevia is a perennial shrub indigenous to Paraguay and Brazil. Today, exceeding South America, all over the world Stevia rebaudiana (Bertoni) represents a new crop from which natural high-potency non-caloric sweeteners can be obtained. Since numerous studies have established certain effects of Stevia rebaudiana (Bertoni) and its extracts on humans, it has become interesting for the pharmaceutical industry (Singh et al., 2012). Among the therapeutic activities attributed to it, hypotensive regulation as well as

*Corresponding author e-mail: jcruiz_ruiz@hotmail.com hypoglycaemic, antimicrobial, and contraceptive activities can be listed (Markovic et al., 2008). As a result, Stevia rebaudiana (Bertoni) has become rather widespread over a wide range of climatic locations around the world and can apparently be successfully grown under different cultivation conditions, since the chemical composition of extracts of the leaves of Stevia rebaudiana (Bertoni) is dependent on the applied conditions of plant cultivation. Drying is one of the efficient methods applied for retaining the chemical composition and antioxidant properties of Stevia rebaudiana (Bertoni) leaves. However, some extent of quality deterioration still occurs during the drying process, so it must be performed within $24 \mathrm{~h}$ after harvesting (AbouArab et al., 2010). The most commonly used methods for drying stevia leaves include the use of equipment or traditional drying carried out under ambient conditions (Espita et al., 2009). Conventional drying with forced air and convection are commonly encountered in dehydration. However, an alternative way to remove excess water from food is the use of traditional methods like shade drying and sun drying (Verás et al., 2012). The success of drying as a method of food preservation depends on the properties of the dried products like colour, nutritive value, and biological activities (Bhuiyan et al., 2011). Some studies on drying treatments of stevia leaves have focused on its effect on the content of glycosides and antioxidants, like convection drying at 100 and $180^{\circ} \mathrm{C}$, freeze drying and shade drying (Ruiz-Ruiz et al., 2015); and on nutritional composition, like sun, oven, and microwave drying (Gasmalla et al., 2014). However, studies are needed on the effect of drying

(C) 2015 Institute of Agrophysics, Polish Academy of Sciences 
treatments on the colour and pigment content, since both parameters may be associated with antioxidant capacity. Dried stevia leaves could also be an important source of nutrients and fibre components. Thus, the aim of the present study was to evaluate the influence of drying methods on the proximate composition, fibre components, and the antioxidant capacities of Stevia rebaudiana leaves from Yucatan, Mexico.

\section{MATERIALS AND METHODS}

Stevia rebaudiana (Bertoni) var. Morita II was obtained from plots established in Tizimín Yucatan, México. The plantation had a crop management according to the production methodology described in Ramírez et al. (2011). Samples were obtained from the first cut of the plot at an age of three months. All chemicals were reagent grade or better and purchased from Sigma Chemical Co. (St. Louis, MO, USA).

Stevia rebaudiana (Bertoni) leaves were subjected to four drying methods:

- radiation drying,

- convection drying,

- shade drying,

- sun drying.

Stoves at $60^{\circ} \mathrm{C}$ were used for the first two treatments. For the shade and sun dried treatments, temperature $\left(29.7^{\circ} \mathrm{C}\right)$ and relative humidity $(70 \%)$ were monitored during the process. To determine the drying kinetics of each treatment, Stevia rebaudiana (Bertoni) leaves were weighed at the beginning and every $4 \mathrm{~h}$ for stove treatments, and every $24 \mathrm{~h}$ for drying under environmental conditions. Drying was stopped until there was no significant weight loss. The leaves were milled to obtain a particle size of $1.0 \mathrm{~mm}$. The samples were stored at room temperature in polyethylene bags until analysis.

Optical properties were determined with a tristimulus colorimeter. Leaf powders were placed directly over the $2.54 \mathrm{~cm}$ diameter aperture for reading and 3 values $\left(\mathrm{L}^{*}\right.$, $\left.a^{*}, b^{*}, \Delta E^{*}, h^{*}\right)$ were recorded: $L$ for lightness on a scale of 0 for black to 100 for white, a - associated with positive values for red and negative for green, and $b-a$ value more negative for yellower and more positive for bluer samples (Singh and Prasad, 2013). $\Delta \mathrm{E}^{*}$ and $\mathrm{h}^{*}$ were calculated using the following formulas:

$$
\begin{gathered}
\Delta \mathrm{E}^{*}=\left[\left(\mathrm{L}_{2}{ }^{*}-\mathrm{L}_{1}^{*}\right)^{2}+\left(\mathrm{a}_{2}^{*}-\mathrm{a}_{1}^{*}\right)^{2}+\left(\mathrm{b}_{2}^{*}-\mathrm{b}_{1}{ }^{*}\right)^{2}\right]^{1 / 2} \\
\mathrm{~h}^{*}=\operatorname{tg}^{-1}\left(\mathrm{~b}^{*} / \mathrm{a}^{*}\right) .
\end{gathered}
$$

For determination of the contents of chlorophylls (a and b) and carotenoids, $10 \mathrm{~g}$ of the sample were placed in $90 \%$ acetone $\left(50 \mathrm{mg} \mathrm{ml}^{-1}\right)$ and homogenized at 1000 r.p.m. for one minute. The homogenate was filtered and centrifuged at 2500 r.p.m. for $10 \mathrm{~min}$. The supernatant was separated and the absorbances were read at $665,645,630$, and $444 \mathrm{~nm}$.
The amounts of chlorophylls and carotenoids were calculated according to the formulas reported in Lichtenthaller (1987).

Chlorophyll: a $(\%)=11.6 * \mathrm{~A} 665-1.31 * \mathrm{~A} 645-$ $0.14 * \mathrm{~A} 630, \mathrm{~b}(\%)=-4.34 * \mathrm{~A} 665+20.7 * \mathrm{~A} 645-4.42 * \mathrm{~A} 630$; carotenoids $(\%)=0.0051 * \mathrm{~A} 444+0.00003$; total pigments $(\%)=$ chlorophyll $\mathrm{a}+$ chlorophyll $\mathrm{b}+$ carotenoids .

The proximate composition was determined using AOAC methods (1998): moisture content (Method 925.09), ash (Method 923.03), crude fat (Method 920.39), crude protein (Method 954.01), and crude fibre (Method 962.09). The carbohydrate content was determined by subtracting the rest of the components from the total dry weight and estimated as the nitrogen-free extract (NFE).

Total dietary fibre (TDF) was determined with a gravimetric enzymatic method (Prosky et al., 1998). Briefly, $1 \mathrm{~g}$ of the sample was weighed into each of the four flasks and $50 \mathrm{ml}$ of phosphate buffer $(50.0 \mathrm{mM}, \mathrm{pH} 6)$ was added to each. The flasks were then placed in a water bath at $100^{\circ} \mathrm{C}$, $0.1 \mathrm{ml}$ of the thermostable $\alpha$-amylase enzyme (Sigma A-3306) was added to each, and then they were agitated at $60 \mathrm{rpm}$ for $15 \mathrm{~min}$. After cooling, $\mathrm{pH}$ was adjusted to 7.5. The flasks were returned to the bath at $60^{\circ} \mathrm{C}, 0.1 \mathrm{ml}$ protease (Sigma P-3910) was added to each, and then they were agitated at $60 \mathrm{rpm}$ for $30 \mathrm{~min}$. After cooling, $\mathrm{pH}$ was adjusted to 4.0. The flasks were again placed in the bath at $60^{\circ} \mathrm{C}, 0.3 \mathrm{ml}$ amyloglucosidase (Sigma A-9913) was added, and then they were agitated for $30 \mathrm{~min}$. Finally, ethanol $95 \%(\mathrm{v} / \mathrm{v})$, preheated to $60^{\circ} \mathrm{C}$, was added at a $1: 4$ $(\mathrm{v} / \mathrm{v})$ ratio. In a vacuum, the flask content was filtered into crucibles containing celite (Sigma C-8656). The residue remaining in the flask was washed three times with $20 \mathrm{ml}$ of ethanol $78 \%(\mathrm{v} / \mathrm{v})$, twice with $10 \mathrm{ml}$ of ethanol $95 \%(\mathrm{v} / \mathrm{v})$, and twice with $10 \mathrm{ml}$ acetone. The crucible content was dried at $105^{\circ} \mathrm{C}$. Protein $(\mathrm{N} \times 6.25)$ was determined for the residue in two crucibles and the residue in the remaining two was burned at $550^{\circ} \mathrm{C}$ for $4 \mathrm{~h}$ :

$$
\operatorname{TDF}(\%)=\frac{[\text { residue weight }(\mathrm{g}) \text { protein }(\mathrm{g}) \text { ash }(\mathrm{g})] 1000}{\text { sample weight }(\mathrm{g})},
$$

Insoluble dietary fibre (IDF) was determined following the method described above, except that the addition of ethanol $95 \%(\mathrm{v} / \mathrm{v})$ at 1:4 (v/v) was omitted.

Soluble dietary fibre (SDF) was calculated by the difference between TDF and IDF: SDF $=$ TDF - IDF.

The fibre components were determined using the methods described by Van Soest et al. (1991). Neutral detergent fibre (NDF) was determined using $50 \mathrm{ml}$ fritted glass crucibles dried at $100^{\circ} \mathrm{C}$ and weighed (W1). One g of the sample was weighed (W2) into a Berzelius beaker. A volume of $100 \mathrm{ml}$ of a neutral-detergent solution (distilled water, sodium borate, EDTA, lauryl sulphate, 2-ethoxyethanol, and disodium phosphate) was added. The $\mathrm{pH}$ was adjusted to 7.1. The sample was heated to boiling for $10 \mathrm{~min}$ and 
refluxed for $60 \mathrm{~min}$. Then the sample was filtered through a tared fritted glass crucible and washed with boiling water three times. The residue was rinsed twice with $40 \mathrm{ml}$ of acetone. Finally, the residue was dried overnight in a convection oven at $100^{\circ} \mathrm{C}$ and weighed (W3). Percent Neutral Detergent Fibre (NDF) was calculated as follows:

$$
\% \mathrm{NDF}=(\mathrm{W} 3-\mathrm{W} 1 / \mathrm{W} 2) 100,
$$

where: $\mathrm{W} 1=$ tare weight of the crucible in grams, $\mathrm{W} 2=$ initial sample weight in grams, W3 = dry weight of the crucible and dry fibre in grams.

For acid detergent fibre (ADF), the samples were processed similar to the method reported for NDF using a volume of $100 \mathrm{ml}$ of an acid detergent solution (distilled water, Cetyl-trimethylammonium bromide, and sulphuric acid $1.0 \mathrm{~N}$ ).

For acid detergent lignin (ADL), the samples were processed similar to the method reported for ADF using a volume of $100 \mathrm{ml}$ of a $72 \% \mathrm{H}_{2} \mathrm{SO}_{4}$ solution. The crucible with a sample was ignited in a muffle furnace at $500^{\circ} \mathrm{C}$ for $2 \mathrm{~h}$. The crucible was weighed (W3).

Cellulose and hemicellulose were calculated as follows: $-\%$ Cellulose $=$ ADF (Cellulose, lignin, cutin) - ADL (Lignin, cutin),

$-\%$ Hemicellulose $=$ NDF (Hemicellulose, cellulose, lignin, cutin) - ADF (Cellulose, lignin, cutin).

The aqueous extract of stevia was obtained according to Woelwer et al. (2010) with some modifications. Uniform particle-sized powder $(500 \mathrm{mg}$ ) was suspended in $5 \mathrm{ml}$ of water that had been warmed up in a water bath at $100^{\circ} \mathrm{C}$ (Cole-Parmer, USA) for $30 \mathrm{~min}$ and subsequently centrifuged for $10 \mathrm{~min}$ at 4000 r.p.m. at $10^{\circ} \mathrm{C}(\mathrm{Z} 300 \mathrm{~K}$, Hermle Labortechnik, Germany). The supernatant was decanted and the solid residue was again added to $5 \mathrm{ml}$ of water, and the procedure was repeated two more times. The aqueous phase obtained from three extractions was decanted into a $25 \mathrm{ml}$ volumetric flask and then filtered through a $0.45 \mu \mathrm{m}$ membrane.

For the 2,2'-Azinobis-(3-Ethylbenzothiazoline-6-Sulfonic Acid, ABTS $\bullet+$ ) decolorization assay, the ABTS + radical cation was produced by reacting 2,2'-azino-bis(3-ethylbenzthiazoline-6-sulphonic acid (ABTS) with potassium persulfate (Rhee et al., 2004). To prepare the stock solution, ABTS was dissolved at a $2 \mathrm{mM}$ concentration in $50 \mathrm{ml}$ phosphate-buffered saline. The ABTS radical cation was produced by reacting $10 \mathrm{ml}$ ABTS stock solution with $40 \mu \mathrm{l}$ $\mathrm{K}_{2} \mathrm{~S}_{4} \mathrm{O}_{8} 70 \mathrm{mM}$ solution and allowing the mixture to stand in darkness at room temperature for $16-17 \mathrm{~h}$ before use. Antioxidants in stevia were analysed by diluting the ABTS $\bullet+$ solution with PBS to an absorbance of 0.800 $\pm 0.030 \mathrm{AU}$ at $734 \mathrm{~nm}$. After adding $990 \mu \mathrm{l}$ of a diluted ABTS $\bullet+$ solution $(A 734 \mathrm{~nm}=0.800 \pm 0.030)$ to $10 \mu \mathrm{l}$ of6-hydroxy-2,5,7,8-tetramethylchroman-2-carboxylicacid (TROLOX) standard (final concentration $0.5-3.5 \mathrm{mM}$ ) in PBS, absorbance was read at room temperature exactly
6 min after initial mixing. All analyses were run in triplicate. Stevia rebaudiana (Bertoni) extract was tested at a concentration of $50 \mathrm{mg} \mathrm{ml}^{-1}$. The percentage decrease in absorbance at $734 \mathrm{~nm}$ was calculated and plotted as a function of the antioxidant concentration of Trolox (0.5$3.5 \mathrm{mM}$ ) for the standard reference data. To calculate the Trolox equivalent antioxidant coefficient (TEAC), the slope of the absorbance inhibition percentage $v s$. antioxidant concentration plot was divided by the slope of the Trolox plot. This produces the TEAC at a specific point in time.

The ferric reducing power assay is based on the reduction of potassium ferricyanide $\left(\mathrm{Fe}^{+3}\right)$ to $\left(\mathrm{F}^{+2}\right)$ in the presence of an antioxidant, KFeIII forming the blue complex [FeII $\left.\left(\mathrm{CN}_{6}\right)\right]$, which absorbs at $700 \mathrm{~nm}$ (Sudha et al., 2011). First, $200 \mu \mathrm{l}$ of the sample $\left(50 \mathrm{mg} \mathrm{ml}^{-1}\right), 500 \mu \mathrm{l}$ of phosphate buffer $(0.2 \mathrm{M}, \mathrm{pH} 6.6)$, and $500 \mu \mathrm{l}$ of potassium ferricyanide $(1 \%)$ were mixed in a test tube. The test tube was then incubated at $50^{\circ} \mathrm{C}$ for $20 \mathrm{~min}$. Subsequently, $500 \mathrm{ml}$ of trichloroacetic acid (10\%) were added, and the tube was centrifuged at $3000 \mathrm{~g}$ for $10 \mathrm{~min}$. An aliquot of $500 \mu \mathrm{l}$ of the supernatant, dissolved in an equal amount of distilled water, was immediately added to $500 \mu \mathrm{l}$ of ferric chloride $(0.1 \%)$. Absorbance was determined at $700 \mathrm{~nm}$. The samples were tested in a range of concentrations from 200 to $1000 \mathrm{mg} \mathrm{ml}^{-1}$.

$\mathrm{Cu}^{2+}$-chelating activity was determined using the pyrocatechol violet reagent (Saiga et al., 2003). Briefly, $1.0 \mathrm{ml}$ of sodium acetate buffer (100 mM, pH 4.9), $100 \mathrm{ml}$ of $\mathrm{Cu}$ (II) standard solution $\left(1.0 \mathrm{mg} \mathrm{ml}^{-1}\right)$, and $100 \mathrm{ml}$ of the sample (containing $200 \mathrm{mg}$ of the sample) were mixed in a test tube. The mixture was allowed to react for $5 \mathrm{~min}$ at room temperature and $25 \mathrm{ml}$ of a pyrocatechol violet solution $(4.0 \mathrm{mM})$ was then added. Absorbance was determined at $632 \mathrm{~nm}$. Copper chelating activity was calculated as follows: Chelating activity $(\%)=(1-$ sample absorbance/ control absorbance) x 100.

$\mathrm{Fe}^{2+}$-chelating activity was determined by measuring the formation of the $\mathrm{Fe}^{2+}$-ferrozine complex (Carter, 1971). Briefly, $1.0 \mathrm{ml}$ of sodium acetate buffer $(100 \mathrm{mM}$, pH 4.9), $100 \mathrm{ml}$ of $\mathrm{Fe}$ (II) standard solution $\left(1.0 \mathrm{mg} \mathrm{ml}^{-1}\right)$, and $100 \mathrm{ml}$ of the sample (containing $200 \mathrm{mg}$ of the sample) was mixed in a test tube. The mixture was allowed to react for $5 \mathrm{~min}$ at room temperature and $50 \mathrm{ml}$ of a ferrozine solution $(40 \mathrm{mM})$ was then added. Absorbance was determined at $562 \mathrm{~nm}$. Iron chelating activity was calculated as follows: Chelating activity $(\%)=(1-$ sample absorbance/ control absorbance) x 100.

All results were analysed using descriptive statistics with a central tendency and dispersion measures. One-way ANOVAs were run to evaluate proximate composition, fibre composition, pigment content, and in vitro antioxidant activities. The least significant difference (LSD) multiple range test was used to determine differences among the 
drying treatments. All analyses were performed according to Montgomery (2004) and processed with the Statgraphics Plus version 5.1 software.

\section{RESULTS AND DISCUSSION}

The drying curves obtained from hot air and convection drying are shown in Fig. 1. For radiation drying, a rapid decrease in the weight difference was observed for the first 8 hours and before the weight was stable, because the vegetal material reached equilibrium in moisture content. Instead, for convection drying, the weight gradually decreased until equilibrium in moisture content was reached after $20 \mathrm{~h}$.

Temperature $\left(60^{\circ} \mathrm{C}\right)$ and time $(24 \mathrm{~h})$ were the same for both treatments; however, the radiation drying treatment was more efficient than the convection treatment, since weight loss is dependent on both temperature and hot air flow in the process of drying. According to Bhuiyan et al. (2011), one of the most common methods of drying is using air as a drying agent. Heat and mass transfer between air and the solid take place in opposite directions. This would explain the results obtained in this study. Dehydration of leaves was also evaluated with traditional drying methods (Fig. 2). For sun drying, a rapid decrease in weight was observed for the first $48 \mathrm{~h}$ and before the weight was stable, because equilibrium in moisture content was reached. The shade drying showed the same behaviour.

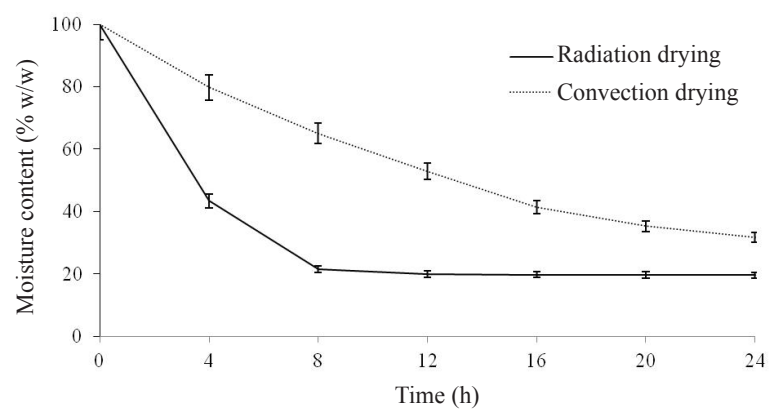

Fig. 1. Moisture content $(\% \mathrm{w} / \mathrm{w})$ in leaves of Stevia rebaudiana (Bertoni) obtained by the radiation and convection drying methods. Data are presented as means $(n=3)$.
The traditional drying method took more time $(48 \mathrm{~h})$ in comparison with the radiation drying $(8 \mathrm{~h})$ and the convection drying $(20 \mathrm{~h})$. Traditional methods such as sun and shade drying could result in contamination and are slow; additionally, their dependence on weather conditions does not allow establishing reproducible conditions to control the process. However, their equipment and energy costs are minor compared with the methods of industrial drying. Thus, these methods could be an alternative for peasants and small industries to process stevia leaves.

The samples dried by the shade drying and sun drying showed the highest values of lightness (L) compared with the radiation and convection drying treatments (Table 1). For the colour-opponent dimension $\mathrm{a}^{*}$, leaf powders obtained by the shade and sun drying treatments showed negative values, which indicates that the components associated with the green colour as the chlorophyll pigments were not degraded during the drying process. In contrast, leaf powders obtained by the radiation and convection drying treatments showed positive values, which indicates that the green colour was partially degraded during the drying process.

Samples dried by the shade drying and sun drying showed the highest values of chroma $\left(\Delta \mathrm{E}^{*}\right)$ compared with the radiation and convection drying treatments. The degradation of pigments during the radiation and convection drying process had a negative impact on the optical properties of the powders. The Hue angle $\left(h^{*}\right)$ sets the kind of

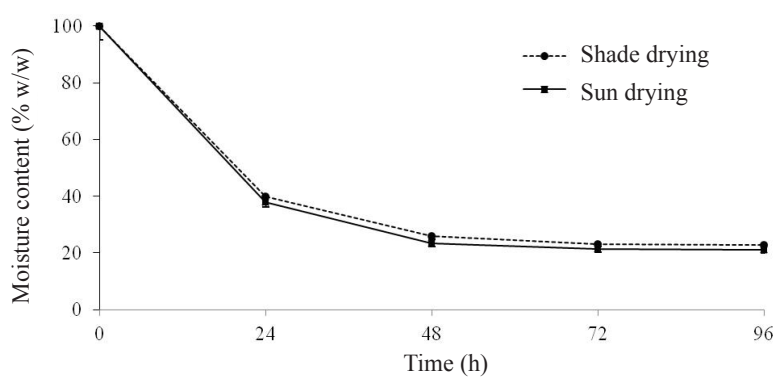

Fig. 2. Moisture content $(\% \mathrm{w} / \mathrm{w})$ in leaves of Stevia rebaudiana (Bertoni) obtained by the shade and sun drying methods. Data are presented as means $(n=3)$.

T a b l e 1. The $\mathrm{L}^{*}, \mathrm{a}^{*}, \mathrm{~b}^{*}, \Delta \mathrm{E}^{*}$ values and hue angle of dried leaf powders of Stevia rebaudiana (Bertoni)

\begin{tabular}{lccccc}
\hline Drying treatment & $\mathrm{L}^{*}$ & $\mathrm{a}^{*}$ & $\mathrm{~b}^{*}$ & $\Delta \mathrm{E}^{*}$ & $\mathrm{~h}^{*}$ \\
\hline Radiation & $43.62 \pm 2.18 \mathrm{a}$ & $1.52 \pm 0.08 \mathrm{a}$ & $24.15 \pm 1.21 \mathrm{a}$ & $24.20 \pm 1.21 \mathrm{a}$ & $86.41 \pm 4.32 \mathrm{a}$ \\
Convection & $44.92 \pm 2.24 \mathrm{a}$ & $1.43 \pm 0.07 \mathrm{a}$ & $23.80 \pm 1.19 \mathrm{a}$ & $23.85 \pm 1.19 \mathrm{a}$ & $86.56 \pm 4.33 \mathrm{a}$ \\
Shade & $61.29 \pm 3.06 \mathrm{c}$ & $-7.71 \pm 0.38 \mathrm{c}$ & $29.51 \pm 1.48 \mathrm{~b}$ & $29.25 \pm 1.46 \mathrm{~b}$ & $104.61 \pm 5.23 \mathrm{~b}$ \\
Sun & $53.86 \pm 2.69 \mathrm{~b}$ & $-2.85 \pm 0.14 \mathrm{~b}$ & $29.52 \pm 1.48 \mathrm{~b}$ & $29.66 \pm 1.48 \mathrm{~b}$ & $95.50 \pm 4.78 \mathrm{ab}$ \\
\hline
\end{tabular}

Data are presented as means $(n=3)$. Different letters in the same line indicate significant difference $(p<0.05)$. 


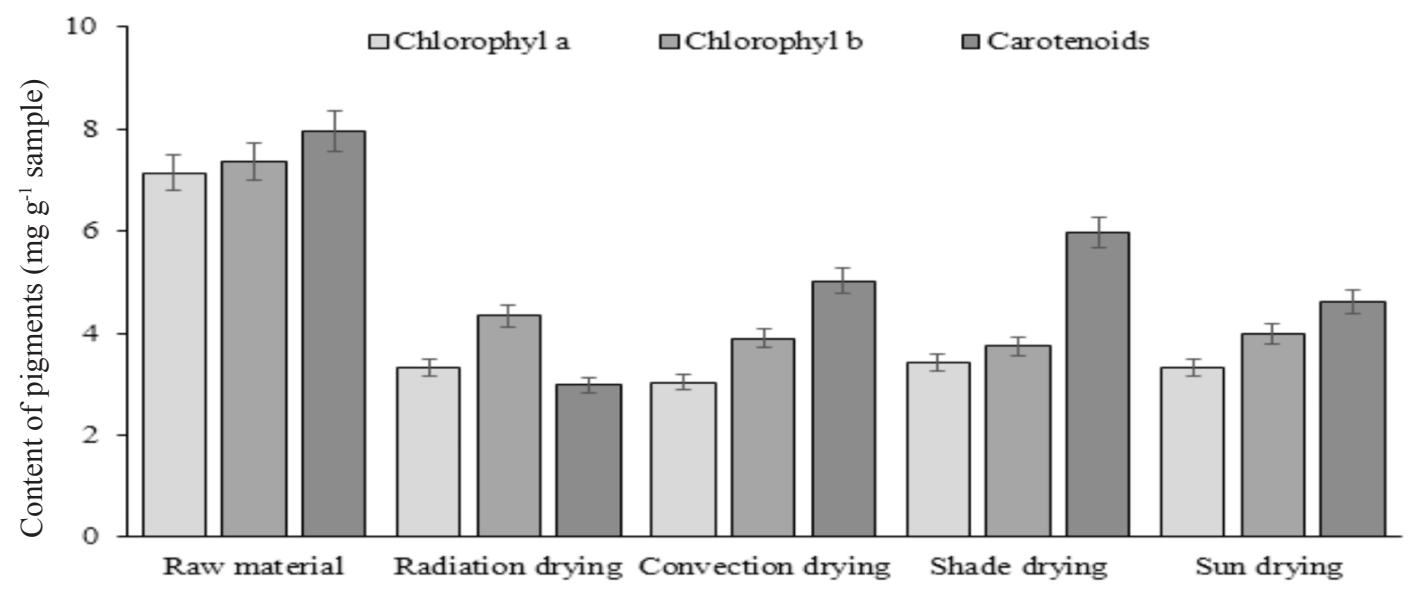

Fig. 3. Composition of chlorophyll (a and b), carotenoids, and total pigments of Stevia rebaudiana (Bertoni) leaves treated by the radiation, convection, shade, and sun drying methods. Data are presented as means $(\mathrm{n}=3)$.

colour. Hue angle values are higher for samples dried by traditional treatments. This indicates that the predominant colour is green and more intense.

Leaf powders obtained by the drying treatments were analysed for the content of chlorophyll $a$ and b, carotenoids, and total pigments (Fig. 3). It was found that the contents of chlorophylls $\mathrm{a}$ and $\mathrm{b}$ did not show any differences between the drying methods. Abou-Arab et al. (2010) quantified the content of chlorophylls, carotenoids, and total pigments in fresh leaves of stevia reporting values of 10.1, 6.6, 3.9, and $20.1 \mathrm{~g} \mathrm{~g}^{-1}$ of chlorophylls a, b, carotenoids, and total pigments, respectively. The same authors reported reductions of 47.4, 41.3, 74.8, and 50.9\% with final values of 4.7, 2.7, 0.76 , and $7.5 \mathrm{~g} \mathrm{~g}^{-1}$ of chlorophylls a, b, carotenoids, and total pigments, respectively, after sun drying. In the present study, the contents of chlorophyll b, carotenoids, and total pigments were higher (Fig. 3).

This may be due to the drying methods not causing excessive degradation of pigments. Shade drying has the highest content of total pigments, followed by convection, sun, and radiation. Usually carotenoids are present together with chlorophylls in chloroplasts, but are also present in other chromoplasts (Krinsky et al., 2005). Although chlorophylls are not considered dietary antioxidants, they are widely distributed among green fruits and vegetables with chlorophyll derivatives predominating in higher plants; they also possess anti-mutagenic activity and antioxidant activity by breaking the radical chain reaction caused by autoxidation via a hydrogen-donating mechanism (Ferruzzi et al., 2002). There are three possible mechanisms that could account for the reaction of carotenoids with radical species, especially singlet oxygen $\left({ }^{1} \mathrm{O}_{2}\right)$ and peroxyl radicals $(\mathrm{ROO} \bullet$ ), including electron transfer, hydrogen abstraction, and the addition of a radical species (Young and Lowe, 2001). Whilst the drying method affects the content of chlorophylls and carotenoids, the remaining contents of both pigments could partially confer antioxidant activity to the Stevia rebaudiana (Bertoni) leaf powder.

Table 2 summarizes the proximate composition of $S$. rebaudiana leaf powders. The results showed that there were significant $(\mathrm{p}<0.05)$ differences between the moisture content of leaves dried using the different methods. The

T a b l e 2. Proximate composition of Stevia rebaudiana (Bertoni) leaves treated by different drying methods

\begin{tabular}{|c|c|c|c|c|}
\hline Component (\%) & Radiation drying & Convection drying & Shade drying & Sun drying \\
\hline Moisture & $8.06 \pm 0.21 \mathrm{c}$ & $7.45 \pm 0.10 b$ & $7.72 \pm 0.24 b c$ & $6.97 \pm 0.22 \mathrm{a}$ \\
\hline Ash & $9.25 \pm 0.28 \mathrm{c}$ & $7.73 \pm 0.29 a$ & $7.89 \pm 0.28 \mathrm{a}$ & $8.63 \pm 0.30 b$ \\
\hline Crude Fat & $3.05 \pm 0.52 \mathrm{a}$ & $3.23 \pm 0.41 \mathrm{a}$ & $3.81 \pm 0.64 \mathrm{a}$ & $3.76 \pm 0.48 \mathrm{a}$ \\
\hline Crude Protein & $13.77 \pm 0.33 b$ & $12.11 \pm 0.66 \mathrm{a}$ & $14.57 \pm 0.38 \mathrm{c}$ & $12.30 \pm 0.35 a$ \\
\hline Crude fiber & $9.52 \pm 0.11 \mathrm{a}$ & $10.50 \pm 0.36 b$ & $10.00 \pm 0.14 b$ & $10.65 \pm 0.51 b$ \\
\hline NFE & $64.32 \pm 1.20 \mathrm{a}$ & $66.43 \pm 1.36 b$ & $63.73 \pm 0.79 a$ & $64.66 \pm 1.04 \mathrm{a}$ \\
\hline
\end{tabular}

Explanations as in Table 1. 
moisture content varied from 6.97 to $8.06 \%$. The radiation drying and shade drying methods gave the highest values followed by convection drying and sun drying.

The contents of ash, crude protein, crude fibre, and NFE in dehydrated S. rebaudiana (Bertoni) leaves are presented in Table 2. One way ANOVA showed significant $(p<0.05)$ differences between the contents for dry samples. The results were similar to those reported by Abou-Arab et al. (2010), who reported values of $5.37 \%$ for moisture, $11.41 \%$ for protein, $3.73 \%$ for crude fat, $15.52 \%$ for crude fibre, $7.41 \%$ for ash, and $61.93 \%$ for carbohydrates in leaves of $S$. rebaudiana (Bertoni) dehydrated by shade drying. All methods of drying reduced the moisture content to values less than $10 \%$. The low levels of moisture of $S$. rebaudiana (Bertoni) leaves enable them to be preserved for long periods. S. rebaudiana (Bertoni) leaves have high amounts of crude protein, crude fibre, and carbohydrates. Considering the primary nutrient composition of the $S$. rebaudiana (Bertoni) leaves, this could be used not only as a sweetener but also as a source of nutrients.

The dietary fibre derived from the cell walls and middle lamellas of plants are not absorbed in the body since it lacks the enzyme to hydrolyse them. However, studies have shown that these components can trap carcinogens and other reactive substances such as bile acids, so that its beneficial effect is exerted directly on the small intestine, which not only removes harmful substances but also alters the microenvironment of the colon (Sankhala et al., 2005). The values of total, insoluble and soluble dietary fibre in dehydrated S. rebaudiana (Bertoni) leaves are presented in Table 3.

There were no significant differences in the TDF content for the differently dried $S$. rebaudiana (Bertoni) leaves. For all treatments, the content of IDF represented between 80 to $90 \%$ of TDF with the lower and higher proportions in the radiation and sun drying methods, respectively. The IDF/SDF ratio ranged between 4 in the radiation drying to
9 in the sun drying method. According to Vásquez-Osorio et al. (2014), when IDF is four times greater than the soluble dietary fibre, the technical and functional properties of fibre increases. In the human gastrointestinal tract, insoluble fibres are not water-soluble. They do not form gels due to their water insolubility and fermentation is severely limited. Soluble fibre dissolves in water forming viscous gels. They bypass the digestion of the small intestine and are easily fermented by the microflora of the large intestine (Wong and Jenkins, 2007).

Cellulose, hemicellulose, non-structural polysaccharides, and lignin are included in the NDF. The ADF is composed of cellulose and lignin, since treatment with the acidic reagent detergent makes the hemicellulose solubilize in its entirety, whilst the ADL is an acid treatment, and only leaves lignin because it is resistant to acid digestions (Van Soest et al., 1991). The content values of NDF, ADF, and $\mathrm{ADL}$ of the $S$. rebaudiana (Bertoni) leaves dried using the four treatments are presented in Table 3. The contents of hemicellulose and cellulose were similar. Cellulose is the principal structural carbohydrate of plants, found in the leaves of $S$. rebaudiana (Bertoni) at a high content. It represents a potential source of use in food, since it has been reported to have poor solubility; it is resistant to digestion in the human gastrointestinal system. These components help to increase the volume of the faecal bolus, promoting peristalsis in the intestine and increasing faecal volume (Sánchez-Muñiz, 2012). Dietary fibre is an abundant source of nutrients including vitamins, minerals, and a slowly digestible energy. In addition, it contains phytochemicals such as pigments, phenolics, carotenoids, lignans, betaglucan, and inulin. These chemicals, secreted by plants, are not currently classified as essential nutrients but may be important factors in human health (Liu, 2003). The synergistic effect of phytochemicals, increased nutrient content and digestive properties are believed to be the mechanism behind the beneficial effects of dietary fibres on the

T a b l e 3. Chemical composition of fiber from Stevia rebaudiana (Bertoni) leaves treated by different drying methods

\begin{tabular}{lcccc}
\hline Component (\%) & Radiation drying & Convection drying & Shade drying & Sun drying \\
\hline Total dietary fiber & $37.73 \pm 1.27 \mathrm{a}$ & $38.05 \pm 6.17 \mathrm{a}$ & $32.77 \pm 2.97 \mathrm{a}$ & $35.16 \pm 1.49 \mathrm{a}$ \\
Insoluble dietary fiber & $30.26 \pm 1.28 \mathrm{a}$ & $31.69 \pm 0.71 \mathrm{a}$ & $29.07 \pm 1.40 \mathrm{a}$ & $31.65 \pm 1.53 \mathrm{a}$ \\
Soluble dietary fiber & $7.48 \pm 0.03 \mathrm{c}$ & $6.36 \pm 0.47 \mathrm{~b}$ & $3.69 \pm 0.17 \mathrm{a}$ & $3.51 \pm 0.07 \mathrm{a}$ \\
Neutral detergent fiber & $17.98 \pm 0.43 \mathrm{~b}$ & $17.81 \pm 0.77 \mathrm{~b}$ & $16.19 \pm 0.15 \mathrm{a}$ & $16.67 \pm 0.71 \mathrm{ab}$ \\
Acid detergent fiber & $13.25 \pm 0.60 \mathrm{a}$ & $13.72 \pm 0.75 \mathrm{~b}$ & $12.26 \pm 0.28 \mathrm{a}$ & $13.54 \pm 1.64 \mathrm{ab}$ \\
Acid detergent lignin & $2.91 \pm 1.15 \mathrm{c}$ & $2.32 \pm 0.27 \mathrm{a}$ & $2.51 \pm 0.21 \mathrm{a}$ & $3.48 \pm 0.50 \mathrm{~b}$ \\
Cellulose & $10.34 \pm 0.73 \mathrm{~b}$ & $11.40 \pm 0.68 \mathrm{~b}$ & $9.75 \pm 0.19 \mathrm{a}$ & $10.07 \pm 1.15 \mathrm{ba}$ \\
Hemicellulose & $4.73 \pm 0.17 \mathrm{~b}$ & $4.09 \pm 0.68 \mathrm{a}$ & $3.93 \pm 0.43 \mathrm{a}$ & $3.23 \pm 0.95 \mathrm{a}$ \\
\hline
\end{tabular}

Explanations as in Table 1. 


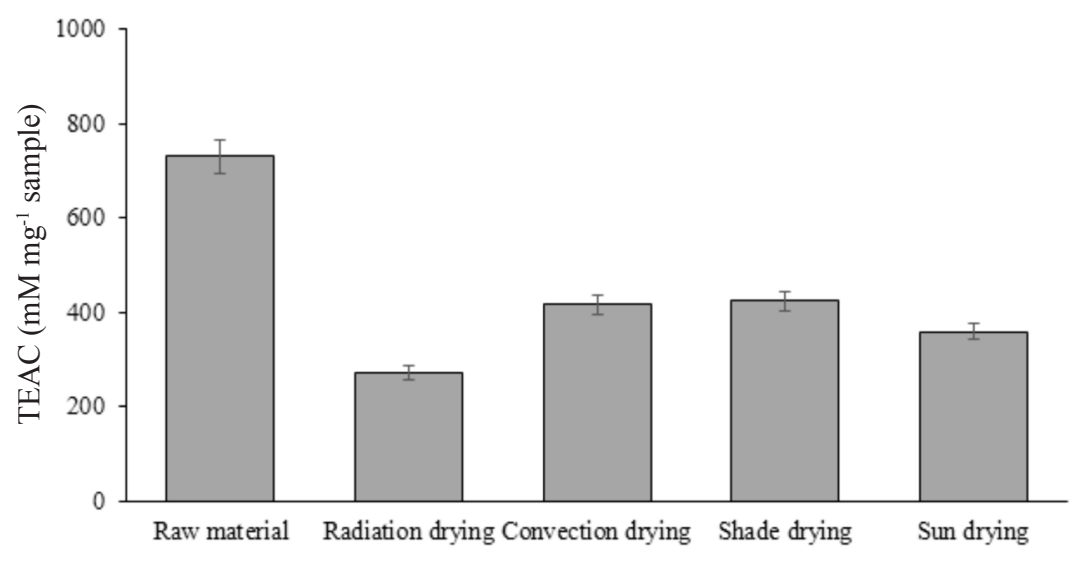

Fig. 4. Trolox equivalent antioxidant capacity (TEAC) of Stevia rebaudiana (Bertoni) leaves treated by the radiation, convection, shade, and sun drying treatments. Data are presented as means $(\mathrm{n}=3)$.

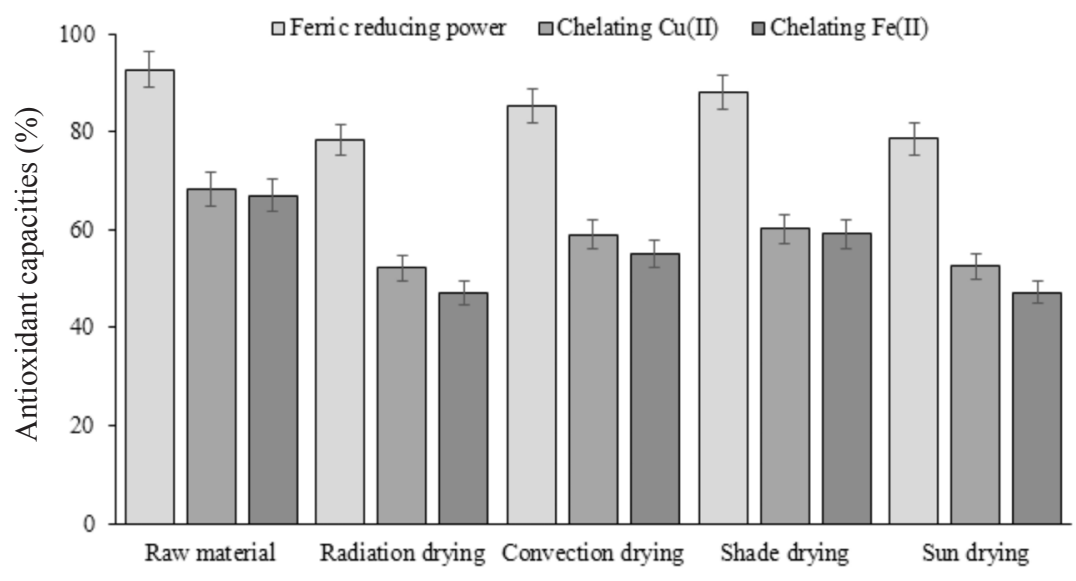

Fig. 5. Antioxidant capacities of Stevia rebaudiana (Bertoni) leaves treated by the radiation, convection, shade, and sun drying treatments. Data are presented as means $(n=3)$.

treatment and prevention of obesity and diabetes (Weickert and Pfeiffer, 2008), reduced cardiovascular diseases, and decreased incidence of certain types of cancer (Lattimer and Haub, 2010).

The TEAC assay is an excellent tool for determining the antioxidant activity of hydrogen-donating antioxidants and chain-breaking antioxidants (Siow and Hui, 2013). The Stevia rebaudiana (Bertoni) extracts efficiently scavenged ABTS radicals with Trolox Equivalent Antioxidant Capacity (TEAC) values, as shown in Fig. 4. The values of TEAC were higher for the convection and shade drying methods.

On the other hand, the values from the results of TEAC decreased in the sun and radiation drying methods. TEAC could be related to the amount of pigments and the loss of pigments could be explained by thermal oxidation and decomposition (Manzocco et al., 2002), which might be the main cause of the antioxidant activity decrease in leaf powders obtained by the radiation and sun drying methods.

Reducing power was measured by direct electron donation in the reduction of $\mathrm{Fe}^{3+}\left(\mathrm{CN}^{-}\right)_{6}-\mathrm{Fe}^{2+}\left(\mathrm{CN}^{-}\right)_{6}$. The product was visualized by forming an intense Prussian blue colour complex; a higher absorbance value indicates a stronger reducing power of the samples. Figure 5 presents the reductive capabilities of the extracts of Stevia rebaudiana (Bertoni). The results of this assay indicate that the extracts are able to donate electrons to reactive radicals, making them form more stable and unreactive species.

Ferric reducing power values were higher for the convection and shade drying methods. On the other hand, ferric reducing power values decreased in the sun and radiation 
drying methods. The ferric reducing properties are generally associated with the presence of reductions by breaking the free radical chain by donating a hydrogen atom (Duh et al., 1999). The ferric reducing power is widely used to evaluate the antioxidant properties of dietary phytochemicals (Luximon-Ramma et al., 2005). A highly positive relationship between phytochemicals and antioxidant activity was observed in many plant species (Oktay et al., 2003).

Metal ion chelating capacity plays a significant role in antioxidant mechanisms, since it reduces the concentration of transition metal ions that are potent catalysts and capable of initiating processes in lipid peroxidation, especially in cellular membranes. The capacities of metal ion chelation of the Stevia rebaudiana (Bertoni) leaf extracts are shown in Fig. 5. The main strategy to avoid the generation of reactive oxygen species, which is associated with redox active metal catalysis, involves chelating metal ions. Stevia rebaudiana (Bertoni) aqueous extracts interfered with the formation of ferrous and cupric complexes, suggesting that they have chelating activity and capture metallic ions. The chelating activity was higher for the convection and shade drying methods. The higher pigment content in aqueous extracts obtained from $S$. rebaudiana (Bertoni) leaves, dried by the convection and shade drying methods showed greater antioxidant activity. The loss of pigments in the radiation and sun drying methods could be explained by thermal oxidation, thermal decomposition, or photodegradation.

\section{CONCLUSIONS}

1. The different drying methods did not have an effect on the primary nutrients and fibre composition of Stevia rebaudiana (Bertoni) leaf powder.

2. Colour, the content of pigments, and antioxidant capacities were affected by the drying method.

3. For preserving primary nutrients, fibre, colour, pigments, and antioxidant capacities of the leaf powder, the convection and shade drying treatments were the most effective.

4. Convection drying is suitable for modern food processing industries while shade drying may be a low cost alternative for farmers.

5. The extracts obtained from Stevia rebaudiana (Bertoni) leaves were found to be effective radical scavengers and possessed good reducing power and chelating activity.

6 . The results of the present study suggest the potential use of the dry processed leaf powders of Stevia rebaudiana (Bertoni) as functional food due to their high nutrient and fibre content, and their multiple antioxidant capacities.

\section{REFERENCES}

Abou-Arab A.E., Abou-Arab A.A., and Abu-Salem M.F., 2010. Physico-chemical assessment of natural sweeteners steviosides produced from Stevia rebaudiana Bertoni plant. African J. Food Sci., 4, 269-281.
AOAC, 1998. Official Methods of Analysis, Association of Official Analytical Chemists, Arlington,VA. Secs. 920.39, 923.03, 925.09, 954.01, 962.09.

Bhuiyan M.H.R., Alam M.M., and Islam N., 2011. The construction and testing of a combined solar and mechanical cabinet dryer. J. Environ. Sci.d Natural Res., 4, 35-40.

Carter P., 1971. Spectrophotometric determination of serum iron at the submicrogram level with a new reagent (ferrozine). Analytical Biochemistry, 40, 450-458.

Duh P.D., Tu Y.Y., and Yen G.C., 1999. Antioxidant activity of the aqueous extract of harng Jyur (Chrysanthemum morifolium Ramat), LWT-Food Sci. Technol., 32, 269-277.

Espitia C.M., Montoya B.R., and Atencio S.L., 2009. Yield of Stevia rebaudiana Bertoni under three population arrangement in middle sinu. Actualidad y Divulgación Científica, 12, 151-161.

Ferruzzi M.G., Bohm V., Courtney P.D., and Schwartz S.J., 2002. Antioxidant and antimutagenic activity of dietary chlorophyll derivatives determined by radical scavenging and bacterial reverse mutagenesis assays. J. Food Sci., 67, 2589-2595.

Gasmalla M.A.A., Yang R., Amadou I., and Hua X., 2014. Nutritional composition of Stevia rebaudiana Bertoni leaf: effect of drying method. Trop. J. Pharma. Res., 13(1), 61-65.

Krinsky N.I. and Johnson E.J., 2005. Carotenoid actions and their relation to health and disease. Molecular Aspects Medicine, 26, 459-516.

Lattimer J.M. and Haub M.D., 2010. Effects of dietary fiber and its components on metabolic health. Nutrients, 2, 12661289.

Lichtenthaller H.K., 1987. Chlorophylls and carotenoids, pigments of photosynthetic biomembranes. Methods Enzymology, 148, 350-382.

Liu R.H., 2003. Health benefits of fruit and vegetables are from additive and synergistic combinations of phytochemicals. American J. Clinical Nutrition, 78, 517S-520S.

Luximon-Ramma A., Bahorun T., Soobrattee A.M., and Aruoma O.I., 2005. Antioxidant activities of phenolic, proanthocyanidin and flavonoid components in extracts of Acacia fistula. J. Agric. Food Chem., 50, 5042-5047.

Manzocco L., Calligaris S., Mastrocola D., Nicoli M.C., and Lerici C.R., 2002. Review of nonenzymatic browning and antioxidant capacity in processed foods. Trends Food Sci. Technol., 11, 340-346.

Markovic I.S., Djarmati Z.A., and Abramovic B.F., 2008. Chemical composition of leaf extracts of Stevia rebaudiana Bertoni grown experimentally in Vojvodina. J. Serbian Chemical Soc., 73, 283-297.

Montgomery D., 2004. Design and analysis of experiments. Limusa-Wiley, México, D.F.

Oktay M., Gulcin I., and Kufrevioglu O.I., 2003. Determination of in vitro antioxidant activity of fennel (Foeniculum vulgare) seed extracts. LWT-Food Sci. Technol., 36, 263-271.

Prosky L., Asp N., Schweizer T., Devries S., and Furda I., 1998. Determination of insoluble, soluble and total dietary fiber in food and food products: interlaboratory study. J. Association Official Analytical Chemists, 71, 1017-1023.

Ramírez J.G., Avilés B.W., Moguel O.Y., Góngora G.S., and May L.C., 2011. Stevia (Stevia rebaudiana Bertoni), a potentialcrop production Mexico. National Institute of Forestry, Agriculture andLivestock. Southeast Regional Research Center, Yucatán, Mexico. 
Rhee S.J., Lee C-Y. J., Kim M-R., and Lee C-H., 2004. Potential antioxidant peptides in rice wine. J. Microbiol. Biotechnol., $14,715-721$.

Ruiz-Ruiz J.C., Moguel-Ordoñez Y.B., Matus-Basto A., and Segura-Campos M.R., 2015. Antioxidant capacity of leaf extracts from two Stevia rebaudiana Bertoni varieties adapted to cultivation in Mexico. Nutr. Hosp., 31, 1163-1170.

Saiga A., Tanabe S., and Nishimura T., 2003. Antioxidant activity of peptides obtained from porcine myofibrillar proteins by protease treatment. J. Agric. Food Chem., 51, 3661-3667.

Sankhala A., Sankhala A.K., Bhatnagar B., and Singh A., 2005. Nutrient composition of less familiar leaves consumed by the tribals of Udaipur region. J. Food Sci. Technol., 42, 446-48.

Sánchez-Muñiz F.J., 2012. Dietary fibre and cardiovascular health. Nutrición Hospitalaria, 27, 31-45.

Singh S., Garg V., Yadav D., Beg M.N., and Sharma N., 2012. In vitro antioxidative and antibacterial activities of various parts of Stevia rebaudiana (Bertoni). J. Pharmacy Pharmaceutical Sci., 4, 468-473.

Singh Y. and Prasad K., 2013. Moringa Oleifera leaf as functional food powder: Characterization and uses. International J. Agric. Food Sci. Technol., 4, 317-324.

Siow L.F. and Hui Y.W., 2013. Comparison on the antioxidant properties of fresh and convection oven-dried guava (Psidium guajava L.). Int. Food Res. J., 20, 639-644.
Sudha G., Priya M.S., Shree R.I., and Vadivukkarasi S., 2011. In vitro free radical scavenging activity of raw pepino fruit (Solanum muricatum A.). Int. J. Current Pharmaceutical Res., 3, 137-140.

Van Soest P.J., Robertson J.B., and Lewis B.A., 1991. Methods for dietary fiber, neutral detergent fiber, and nonstarch polysacharides in relation to animal nutrition. J. Dairy Sci., 74, 358-397.

Vásquez-Osorio D., Vélez-Acosta L.M., and Hincapi G.A., 2014. Analysis of nutritional and functional properties of dry guava. Ingeniería Universidad Bogotá, 18, 159-175.

Verás A.O.M., Béttega R., Freire F.B., Barrozo M.A.S., and Freire J.T., 2012. Drying kinetics, structural characteristics and vitamin $\mathrm{C}$ retention of pepper (Capsicum baccatum) during convective and freeze drying. Brazilian J. Chem. Eng., 29, 741-750.

Weickert M.O. and Pfeiffer A.F., 2008. Metabolic effects of dietary fiber consumption and prevention of diabetes. J. Nutrition, 138, 439-442.

Woelwer R.U., Lankes C., Wawrzun A., and Wüst M., 2010. Improved HPLC method for evaluation of the major steviol glycosides in leaves of Stevia rebaudiana. European Food Res. Technol., 231, 581-588.

Wong J.M. and Jenkins D.J., 2007. Carbohydrate digestibility and metabolic effects. J. Nutrition, 137, 2539S-2546S.

Young A.J. and Lowe G.M., 2001. Antioxidant and prooxidant properties of carotenoids. Archives Biochem. Biophys., 385, 20-27. 